\title{
Economic Analysis of Rice Production in Central Agricultural Zone of Adamawa State, Nigeria
}

\author{
Usman, J. \\ Department of Agricultural Economics and Extension Adamawa State University, Mubi, Nigeria
}

\begin{abstract}
This paper analysed the economics of rice production in central agricultural zone of Adamawa state, Nigeria. Purposive and simple random sampling techniques were used to collect primary data from 130 rice farmers through field survey using well designed pre-tested schedule. Descriptive statistics, cost concept, stochastic frontier cost model, as well as Garrett's ranking technique were used to analysed the data. The results revealed that rice production was dominated by young literate men who had been in rice production for more than 20 years. Rice production was found to be profitable with net income over cost $A_{1}$ which is the direct cost involved in rice production as $\$ 146,049.11$; while over cost $C_{3}$ which is the total cost of cultivation of rice was $\$ 100,083.62$. The stochastic cost frontier model shows three parameters seed, family labour and agro-chemicals had positive and significant effect on the revenue of the rice farmers. Inadequate rainfalls, shortage of labour, clashes with pastoralist were the major constrains associated with rice production in the study area. The study suggest that government policies should be geared towards developing and establishing new fertilizer and agro-chemicals industries to ease the cost of farm inputs, as well as intensify farmer grazer conflict resolution programmes.
\end{abstract}

Key Words: Clashes with pastoralist Cost concept Nigeria Rice production

\section{INTRODUCTION}

\section{Background of the Study}

Nigeria is endowed with human and natural resources with verse fertile agricultural land suitable for cultivation of different crops. It has a total land area of 923,768 sq $\mathrm{km}$ comprising of $910,768 \mathrm{sq} \mathrm{km}$ land area and $13,000 \mathrm{sq} \mathrm{km}$ of water ranking $13^{\text {th }}$ in the world (Nigeria Economy Starts, 2012). According to Trading economics, (2018) Gross Domestic Product (GDP) from agriculture in Nigeria averaged $\$ 3,771,185.70$ million from 2010 until 2017, reaching an all-time high of $\$ 5,189,365.99$ million in the third quarter of 2017 and a record low of $\$ 2,594,759.86$ million in the first quarter of 2010. This placed Nigeria at $6^{\text {th }}$ top agricultural countries by GDP contribution in the world after China, India, United States, Indonesia and Brazil in 2017.

In Nigeria there are different methods of cultivating rice ranging from rain fed upland rice predominantly in the southern part of country but can also be found in north, the rain fed lowland rice found mainly along the flooded river valleys which accounts for more than half of the total rice land area in Nigeria, the irrigated rice that account for $16 \%$ of total rice land area in Nigeria others include deep-water/floating mangrove found in Sokoto Rima valleys and Kebbi where flooding achieves a depth of $60-100 \mathrm{~cm}$ and mangrove swamp rice found where the ocean's tidal action causes inundation at high tide and drainage at low tide (Sanusi, 2014). 
Rice is a seed cultivated in high water lands. It is the $2^{\text {nd }}$ most produced cereal in the world after maize. It has enough calories to full the human energy. It can be grown on any place e.g. hills, swampy, plane areas. Largest rice producing countries need more labour to cultivate the seeds. It is an important cereal crop in Nigeria grown in both wet and dry season. There had been large variations in the production of rice in Nigeria from 1994-2016 (Fig. 1). It was only 2.4 million tonnes in 1994-5 which rose to 3.1 million tonnes in 1996 and remains steady till 2006 when it rose to 4 million tonnes. Rice production rose to 6.2 million tonnes in 2015 recording the highest level of production in the country in 3.1 million hectares of land. However, there was a decline in production and area to 6.0 million tonnes and 2.9 million hectares respectively in 2016 cropping season (FAOSTAT, 2018).

This study, which was carried out in central agricultural zone of Adamawa state, Nigeria seeks to analyse the economics of rice production under the following objectives: to assess the socioeconomic status of rice farmers, examine the cost and return, analyse the allocative efficiency and identify the constrains in rice production. Understanding and addressing these objectives will be a good step towards improving the standard of living of the people and attaining the target of rice self-sufficient in Nigeria.

\section{Figure 1}

\section{Production/Yield quantities of Rice, paddy in Nigeria}

$1994-2016$

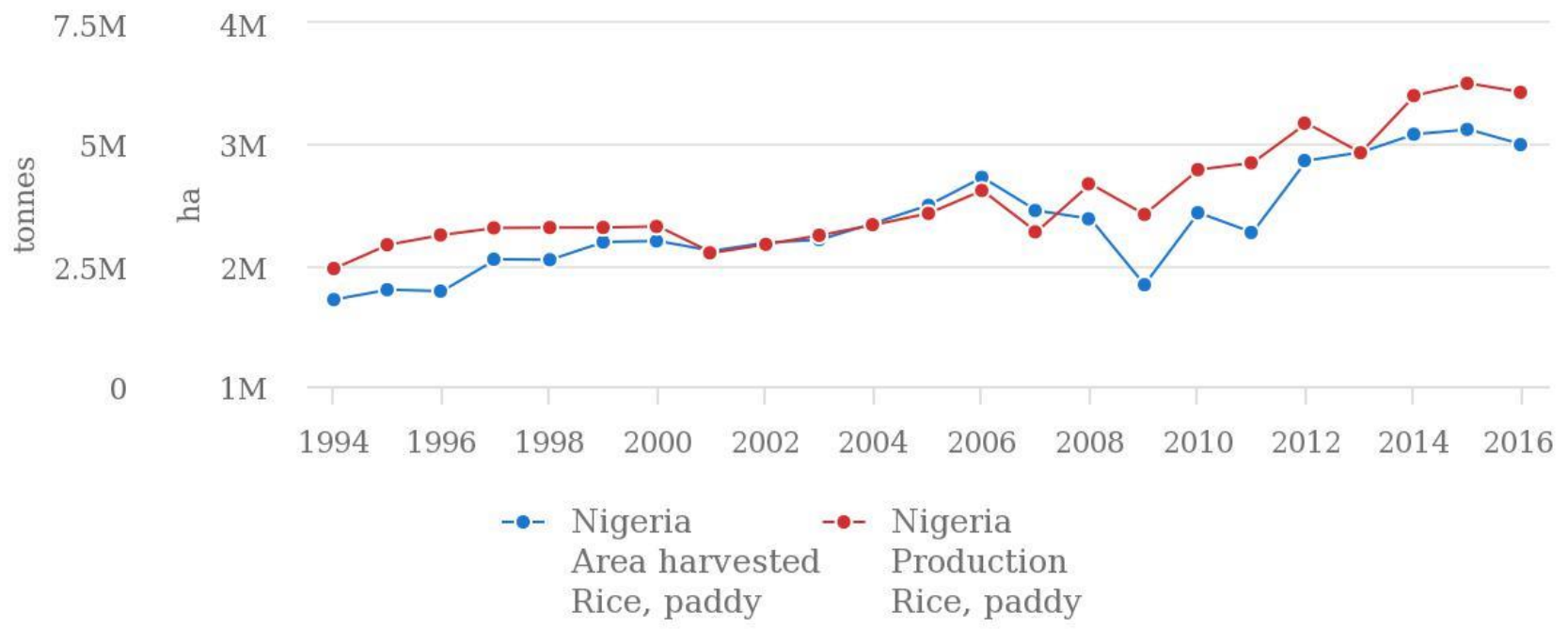

\section{METHODOLOGY}

\section{Study Area}

Adamawa State north-eastern part of Nigeria is divided in to four agricultural zones based on soil; climate and vegetation. The central zone is noted for its numerous low land areas which are prone to flooding during the wet season. Coupled with a moderate mean annual rainfall of about $900 \mathrm{~m}$, this zone is ideal for the production of crops like rice and maize. Apart from the large swampy areas (fadamas) found in parts of Yola, Fufore and Song local government areas of this zone, which support rice production during wet seasons, irrigated rice production is also practiced where 
such fadamas are located near large irrigation water (Sajo and Kadams, 1999).

\section{Sampling Procedure}

Four out of Five local government areas (LGAs) in Adamawa central agricultural zone (Song, Fufore, Yola- North and South) were purposively selected based on their level of rice production (Table 1). Eight districts (Suktu, Mboi, Ribadu,
Gurin, Jimeta, Ngolomba, Yola and Namtari) two from each of the selected LGAs were purposely selected based on their level of rice production. Sixteen villages (Jimbo, Kupta, Gudu, Hada, Dulo, Dasin, Chikito, Pukka, Ngerio, Nboromji, Ngolomba, Jambutu, Ngurore, Ngoduwo, Bole and Rugange) two villages from each of the selected districts were also purposely selected based on their level of rice production. Thereafter, 130 respondents were randomly selected and used for the study.

TABLE 1

Distribution of Sampled Farmers

\begin{tabular}{lllc}
\hline Local Government Areas & Name of Districts & Villages & No. of Respondents \\
\hline Song & 1. Suktu & 1. Jimbo & 10 \\
& & 2. kupta & 7 \\
& 2. Gudu Mboi & 3. Gudu & 8 \\
Fufore & 1. Ribadu & 4. Hada & 8 \\
& & 1. Dasin & 10 \\
& 2. Gurin & 2. Dulo & 7 \\
& & 3. Chikito & 9 \\
Yola- North & 1. Jemita & 4. Pukka & 6 \\
& & 1. Ngerio & 10 \\
& 2. Ngolomba & 2. Nboromji & 8 \\
& & 3. Ngolomba & 8 \\
Yola-South & \multirow{3}{*}{ 1. Yola } & 4. Jambutu & 7 \\
& \multirow{2}{*}{ 2. Namtari } & 1. Bole & 6 \\
& & 2. Rugange & 10 \\
& & 3. Ngurore & 7 \\
& & 4. Ngoduwo & 9 \\
\hline
\end{tabular}

\section{Sources and Period of Data Collection}

The primary data for the present study were collected in a field survey through direct interview with rice farmers in Adamawa central agricultural zone in November 2017. A total of 130 rice farmers were interviewed using pretested schedule in the study area. Secondary data were collected from relevant published research articles and text books. 


\section{Analytical Tool}

Descriptive and inferential statistics were used to analysed the data.

The cost concept developed by the Commission on Agricultural Cost and Price (CACP) was adopted for the estimation of cost of cultivation of rice in the study area. The different costs were calculated as:

Cost $\mathrm{A}_{1}=$ All actual expenses in cash and kind incurred in production by owner.

These include: cost of seed, cost incurred on manures and fertilizers, plant protection chemicals, land revenue, wages of hired human labour, hired labour charges of implements and machinery, charges for bullock labour, depreciation on fixed assets, excluding family labour.

Cost $A_{2}=$ Cost $A_{1}+$ rent paid for leased-in land.

Cost $A_{2}+F L=$ Cost $A_{2}+$ imputed value of family labour.

Cost $\mathrm{B}_{1}=$ Cost $\mathrm{A}_{1}+$ interest on value of owned fixed capital assets (excluding land).

Cost $\mathrm{B}_{2}=$ Cost $\mathrm{B}_{1}+$ rental value of owned

land (net of land revenue) and rent paid for leased-in land.

Cost $\mathrm{C}_{1}=$ Cost $\mathrm{B}_{1}+$ imputed value of family labour.

Cost $\mathrm{C}_{2}=$ Cost $\mathrm{B}_{2}+$ imputed value of family labour.

Cost C3 $=$ Cost $\mathrm{C}_{2}+10$ per cent of $\operatorname{cost} \mathrm{C}_{2}$ on account of managerial functions

performed by the farmers.

(Narayanamoorthy, 2013)

\section{Allocative efficiency analysis}

Allocative Efficiency (AE) refers to the ability to produce at a given level of output using the cost-minimizing input ratios. It can be measured through cost efficiency, revenue

Where: efficiency and profit efficiency, which is a combination of the two (Wu, 1979). Cost efficiency is the ratio of respondents minimum possible production cost to actual production cost. Revenue efficiency is the ratio of the maximum possible income a respondent can receive to the actual income a respondent received. Profit efficiency is a combination of cost efficiency and revenue efficiency (Sihlongonyane, et al. 2014). A producer is allocative efficient if production occurs in a sub set of the economic boundary of the production possibilities set that satisfies the producer's behavioral objective. The Allocative Efficiency (AE) in the use of variable inputs is given as the ratio of,

$\mathrm{AE}_{\mathrm{ij}} \quad=\mathrm{MGR}_{\mathrm{j}} / \mathrm{OGR}_{\mathrm{ij}}$

Where: $\mathrm{MGR}_{\mathrm{j}}$ is maximum possible gross revenue of the $\mathrm{j}^{\text {th }}$ farms; and $\mathrm{OGR}_{\mathrm{ij}}$ is gross revenue at the optimum level of the $i^{\text {th }}$ input with all input remaining at same level of the activity by $j^{\text {th }}$ farmer.

In order to determine optimal use of a resource, keeping the other resource constant, Marginal Value of Product (MVP) and opportunity cost (factor) of that resources was compared. It was estimated from the parameter of Cob Douglas production function. The criterion for determining optimality of resource use:

MVP/MPC > 1 underutilization of resource $\mathrm{MVP} / \mathrm{MPC}=1$ optimal use of resource MVP/MPC $<1$ excess use of resources The corresponding cost frontier of Cobb-Douglas functional form which is the basis of estimating the allocative efficiencies of rice farmers in the study area is specify and defined as follows:

$\operatorname{InC}_{\mathrm{ij}}=\beta_{0}+\beta_{1} \operatorname{InP}_{1 \mathrm{ij}}+\beta_{2} \operatorname{InP}_{2 \mathrm{ij}}+-----+\beta_{6} \operatorname{InP}_{6 \mathrm{ij}}+\mathrm{V}_{\mathrm{ij}}-\mathrm{U}_{\mathrm{ij}}$

Subscript $i j$ refers to the $\mathrm{j}^{\text {th }}$ observation of $\mathrm{i}^{\text {th }}$ farmers. 
Where: $C_{i j}$ is total cost of production ( $)$, In is logarithm to base e, $\mathrm{P}_{1}$ is rental value of own land (N), $\mathrm{P}_{2}$ is cost of seed ( $), \mathrm{P}_{3}$ is cost of hired labour ( ), $\mathrm{P}_{4}$ is cost of family labour ( $), \mathrm{P}_{5}$ is cost of agro-chemicals ( $), \mathrm{P}_{6}$ is cost of fertilizer $(\#), V_{i}$ is the random variable which is assumed to be normally distributed $\mathrm{N}(0, \delta 2 \mathrm{v})$ and independent of $\mathrm{U}_{\mathrm{i}}$. It assumed to account for random factors such as weather, risk and measurement error and $\mathrm{U}_{\mathrm{i}}=$ is the non- negative error term having zero mean, and constant variance i.e. $\mathrm{N}(0, \delta 2 \mathrm{U})(\mathrm{Xu}$ and Jeffrey, 1998).

Garret's ranking technique was adopted to identify constraints in rice cultivation. The respondents were asked to rank ten set of constraints that were related to rice production. The order of merits that were given by the respondents was converted into ranks using the following formula given by Jagdish et al. (2008).

Percentage Position $=\frac{100\left(R_{i j}-0.50\right)}{N_{j}}$

Where,

$\mathrm{R}_{\mathrm{ij}}=$ Rank given for the $\mathrm{i}^{\text {th }}$ constraints by the $\mathrm{j}^{\text {th }}$ farmer;

$\mathrm{N}_{\mathrm{j}}=$ Number of constraints ranked by the $\mathrm{j}^{\text {th }}$ individual.

\section{RESULTS AND DISCUSSION}

\section{Socio-economic status of the respondents}

Socio-economic status of a farmer is an economic and sociological combined total measure of his work experience or family's economic and social position in relation to others, based on age, gender, household size, literacy level, farming experience, extension contacts etc. These characteristics as they relate to rice farmers in central agricultural zone of Adamawa state, Nigeria were presented in Table 2. The results revealed that rice production was dominated by young $(88.46 \%)$, literate $(65.38 \%)$, men $(78.46 \%)$ who had been in rice production for more than 20 years. This accord the report made by Matanmi et al. (2011) that rice production is dominated by young married men who are literate and had been in production for long in their study on perceived factors limiting rice production in Patigi local government area of Kwara state, Nigeria. This implies that rice farmers have the ability to accept and adopt new agricultural production systems and techniques, and so they have the capacity to undertake agricultural production activities with fewer constraints. The mean household size was found to be 8.00 which indicate that farmers will spend less on hired lobour since the households had a high labour force to carry out agricultural production. Majority of them $(80.77 \%)$ had no contacts with extension agents. The result shows that most of the farmers are likely to be technically less efficient in the use of improved methods and practices in rice production since lack of extension services hinders farmers from adopting new innovations.

\section{Cost of rice production in central agricultural zone of Adamawa state, Nigeria}

Table 3 revealed the cost of cultivating rice in central agricultural zone of Adamawa state, Nigeria. On the average cost $\mathrm{C}_{3}$ (total cost) was found to be $\$ 121,166.38$. The average variable cost was found to occupy 74.86 percent of cost $\mathrm{C}_{3}$ with cost of family labour, fertilizer, agrochemicals (14.44, 12.42 and 11.64 per cent) respectively of the total cost of cultivation. While the average fixed cost was found to occupy 16.05 percent of cost $\mathrm{C}_{3}$. The result agrees with Girei et al. (2016) who also reported an average total cost of $\$ 135,432$ for two cycles per annum from dry season rice production with cost of labour accounted for the largest proportion of the total cost of the production. 
TABLE 2

Socio-economic production

\begin{tabular}{|c|c|c|c|}
\hline \multirow{32}{*}{ production } & Factors & Frequency & Percentage \\
\hline & Gender & & \\
\hline & Male & 102 & 78.46 \\
\hline & Female & 28 & 21.54 \\
\hline & Total & 130 & 100.00 \\
\hline & Age (years) & & \\
\hline & $15-24$ & 65 & 50.00 \\
\hline & $25-34$ & 50 & 38.46 \\
\hline & $35-44$ & 10 & 7.69 \\
\hline & $>45$ & 05 & 3.85 \\
\hline & Total & 130 & 100.00 \\
\hline & Mean & 26.04 & \\
\hline & Literacy level & & \\
\hline & No formal Edu. & 45 & 34.62 \\
\hline & Formal education & 85 & 65.38 \\
\hline & Total & 130 & 100.00 \\
\hline & Experience (years) & & \\
\hline & $\leq 20$ & 70 & 53.85 \\
\hline & $21-40$ & 48 & 36.92 \\
\hline & $\geq 41$ & 12 & 9.23 \\
\hline & Total & 130 & 100.00 \\
\hline & Mean & 21.58 & \\
\hline & Household size & & \\
\hline & $1-10$ & 102 & 78.46 \\
\hline & $11-20$ & 25 & 19.23 \\
\hline & $\geq 21$ & 03 & 2.31 \\
\hline & Total & 130 & 100.00 \\
\hline & Mean & 7.88 & \\
\hline & Extension contacts & & \\
\hline & Yes & 25 & 19.23 \\
\hline & No & 105 & 80.77 \\
\hline & Total & 130 & 100.00 \\
\hline
\end{tabular}

characteristics of rice 
Operational Cost

Amount (\#)
$\%$ to total cost

(C3)

\begin{tabular}{|c|c|c|}
\hline Seed & $10,115.57$ & 8.35 \\
\hline Family Labour & $17,500.00$ & 14.44 \\
\hline Hired Labour & $13,599.17$ & 11.22 \\
\hline Machine Labour & $4,150.12$ & 3.43 \\
\hline Bullock & $2,000.64$ & 1.65 \\
\hline Fertilizer & $15,050.33$ & 12.42 \\
\hline Chemicals & $14,100.12$ & 11.64 \\
\hline Farm yard Manure & 884.85 & 0.73 \\
\hline Storage & 5261.68 & 4.34 \\
\hline Transportation & $4,000.32$ & 3.30 \\
\hline Repair of Farm House & 759.55 & 0.63 \\
\hline Total working capital & $87,422.35$ & 72.15 \\
\hline Interest on working Capital & $3,278.34$ & 2.71 \\
\hline Sub Total & $90,700.69$ & 74.86 \\
\hline Fixed Cost & & 0.00 \\
\hline Depreciation & $2,000.22$ & 1.65 \\
\hline Rent paid for leased land & $6,000.00$ & 4.95 \\
\hline Rent value for own Land & $10,500.00$ & 8.67 \\
\hline $\begin{array}{l}\text { Interest on fixed capital excluding } \\
\text { Land }\end{array}$ & 950.36 & 0.78 \\
\hline Sub total & $19,450.58$ & 16.05 \\
\hline $10 \%$ Managerial Cost & $11,015.13$ & 9.09 \\
\hline Cost Of Cultivation & & 0.00 \\
\hline Cost A1 & $75,200.89$ & 62.06 \\
\hline Cost A2 & $81,200.89$ & 67.02 \\
\hline Cost $\mathrm{A} 2+\mathrm{FL}$ & $98,700.89$ & 81.46 \\
\hline Cost B1 & $76,151.25$ & 62.85 \\
\hline Cost B2 & $92,651.25$ & 76.47 \\
\hline Cost $\mathrm{C} 1$ & $93,651.25$ & 77.29 \\
\hline Cost C2 & $110,151.25$ & 90.91 \\
\hline Cost C3 & $121,166.38$ & 100.00 \\
\hline
\end{tabular}

Cost of Cultivation of Rice in Central Agricultural Zone of Adamawa state

TABLE 4 


\section{Cost and Return in Rice \\ Production}

\section{Cost and return in rice production in central agricultural zone of Adamawa state, Nigeria}

Per hectare crop yield for rice production was found to be 29.00 bags for main product and 15.00 $\mathrm{kg}$ for by-product (Table 4). The gross income and margin was found to be $\$ 221,250$ and $\$ 130,549.31$ respectively. The net income over cost A1 which is the direct cost involved in rice production was $¥ 146,049.11$;

while over cost $\mathrm{C}_{3}$ which is the total cost of cultivation of rice was $\$ 100,083.62$. The input-output ratio analysis was worked out on the basis of cost $A_{1}$ to $\mathrm{C}_{3}$. Cost $\mathrm{A}_{1}$ has the highest ratio of 1: 2.94 while cost $\mathrm{C}_{3}$ has the lowest ratio of $1: 1.83$ in central

By Product $(\mathrm{kg} / \mathrm{Ha})$

Market Price (

Grain/Main Product

By Product

Gross Income ( $\mathrm{N} / \mathrm{Ha})$

Gross Margin ( $\mathrm{N} / \mathrm{Ha})$

Net Income Over

Cost A1

Cost A2

Cost C3

Cost C3

Cost A1

Cost A2

Cost A2+ FL

Cost B1

Cost B2

Cost $\mathrm{C} 1$

Cost $\mathrm{C} 2$

Cost C3

\section{Total cost} 29

7,500

250

221,250

$130,549.31$

$146,049.11$

$140,049.11$

$122,549.11$

$145,098.75$

$128,598.75$

$127,598.75$

$111,098.75$

$100,083.62$

1: 2.94

1: 2.72

$1: 2.24$

1: 2.91

1: 2.39

$1: 2.36$

$1: 2.01$

$1: 1.83$

Cost of Production ( $\mathrm{N} / \mathrm{Ha})$

$2,593.13$

$2,800.03$

$3,403.48$

$2,625.91$

$3,194.87$

$3,229.35$

$3,798.32$ agricultural zone of Adamawa state, Nigeria. The study concord the finding of Usman 
2018 that rice production is profitable in song local government with net income over

\section{Allocative efficiency}

Table 5 depicts the Maximum Likelihood Estimate (MLE) of the parameters of the stochastic cost frontier model used in estimating allocative efficiency of rice farmers in central agricultural zone of Adamawa state, Nigeria. . The result shows that three out of six parameters measured (seed, family labour and agro-chemicals) were positively significant towards the efficiency of farmers at five and ten percent level which implies that the revenue in rice production will increase by $0.079,0.172$ and 0.012 percent respectively on one percent increase in the study area. Samarpitha et al. (2016) also found human labour as the major determinant of rice productivity in Nalgonda district of Telangana state.

The inefficiency parameters included in the model specifically, those related to farmers' socio-economic characteristics such as age, gender, family size, level of education, farming experience and extension contacts were also revealed in Table 5. The signs in the inefficiency model were explained in the opposite way such that a negative sign indicates decrease in allocative inefficiency while positive sign indicates increase. The estimated coefficient of age, education and extension contacts with $-0.014,-0.015$, and 0.399 respectively carried the expected negative sign and was statistically significant at ten percent level of significance in the study area. This implies that one unit increase in these variables will cost $C_{3}$ of $\$ 45,176.15$ per hectare.

decrease allocative inefficiency as well as increase the output of the rice production in central agricultural zone of Adamawa state, Nigeria. The coefficient of sigma squared and gamma in the study area were 4.846 and 0.765 and it was statistically significant at ten and one percent level of significance respectively. Thus, the diagnostic statistics confirm the relevance of the stochastic production function.

Table 5 further revealed the results of the allocative efficiency indices of rice farmers in central agricultural zone of Adamawa state, Nigeria. The mean allocative efficiency was found to be 0.89 indicated that an average farmer in the study area has the scope for increasing allocative efficiency by 11 per cent in the short-run under the existing technology. This would enable the average farmer equate the marginal value product (MVP) of the inputs to the total production. The superlative practice farmers operated at about 98 per cent efficiency; while the least practice farmers were found to operate at about 54 percent efficiency level in the study area. It is in line with the finding of Samarpitha et al. (2016) who also reported high mean allocative efficiency of 88.36 per cent in their study on technical, economic and allocative efficiencies of rice farms in Nalgonda district of Telangana state.

TABLE 5

Maximum Likelihood Estimate of Stochastic Frontier Cost function for Rice Farmers in Central Agricultural zone of Adamawa State, Nigeria

Variables Production Factors Parameter Coefficient t-ratio




\begin{tabular}{llll}
\hline Constant & & & \\
Rental value of own land $\left(\mathrm{P}_{1}\right)$ & $\beta_{\mathrm{o}}$ & 2.5966 & $3.8604^{*}$ \\
Cost of Seed $\left(\mathrm{P}_{2}\right)$ & $\beta_{1}$ & 0.0909 & $0.5162 \mathrm{NS}$ \\
Cost of Hired labour $\left(\mathrm{P}_{3}\right)$ & $\beta_{2}$ & 0.0787 & $2.0109^{* *}$ \\
Cost of Family labour $\left(\mathrm{P}_{4}\right)$ & $\beta_{3}$ & 0.0073 & $1.2843 \mathrm{NS}$ \\
Cost of Chemicals $\left(\mathrm{P}_{5}\right)$ & $\beta_{4}$ & 0.1721 & $2.4576^{* *}$ \\
Cost of Fertilizer $\left(\mathrm{P}_{6}\right)$ & $\beta_{5}$ & 0.0120 & $1.6668^{* * *}$ \\
Inefficiency Model & $\beta_{6}$ & 0.0233 & $0.1555 \mathrm{NS}$ \\
Constant & & & \\
Age $\left(\mathrm{Z}_{1}\right)$ & $\delta_{0}$ & -0.7152 & $-1.3440 \mathrm{NS}$ \\
Sex $\left(\mathrm{Z}_{2}\right)$ & $\delta_{2}$ & -0.0146 & $-1.9488^{* * *}$ \\
Farming Experience $\left(\mathrm{Z}_{3}\right)$ & $\delta_{1}$ & -0.0432 & $-0.2951 \mathrm{NS}$ \\
Education $\left(\mathrm{Z}_{4}\right)$ & $\delta_{3}$ & 0.065 & $0.1623 \mathrm{NS}$ \\
Family Size $\left(\mathrm{Z}_{5}\right)$ & $\delta_{4}$ & -0.0151 & $-1.6529^{* * *}$ \\
Extension Contacts $\left(\mathrm{Z}_{6}\right)$ & $\delta_{5}$ & 0.1292 & $0.9220 \mathrm{NS}$ \\
Variance Parameters & $\delta_{6}$ & -0.3990 & $-1.8252^{* * *}$ \\
Sigma-Square $(\delta)$ & & & \\
Gamma $(\Upsilon)$ & & 4.8461 & $1.8252^{* * *}$ \\
Efficiency Rating & & 0.7648 & $4.6893^{*}$ \\
Minimum efficiency & & & \\
Maximum efficiency & 0.54 & & \\
Mean efficiency & 0.98 & & \\
\hline Significant at1\% & $\mathbf{0 . 8 9}$ & & \\
\hline
\end{tabular}

* Significant at $1 \%$ level of significance;

** Significant at5\% level of significance.

*** Significant at $10 \%$ level of significance

\section{Constrains in Rice Production}

To identify and prioritize ten constrains in rice production in the study area. The percentage position of each rank was converted into scores using Garret's table. For each constraint, scores of individual respondents was added together and then divided by total number of respondents for whom scores was added. Thus, mean score for each constraint was ranked by arranging them in the descending order (Table 6). Table 7 depicts constrains in rice production in central agricultural zone of Adamawa state. Going by the average total mean for the ten constraints sampled, the result shows that inadequate rainfalls, shortage of labour, clashes with pastoralist, striga infestation and inadequate farm credit were identified as the major constrains associated with rice production in the study area. However, these constrains were concisely expressed by the respondents as follows:

Rice requires ample water for its production and rainfalls; to a major extent provide this water through the soil for the development and growth of plants. Inadequate rainfalls poses a serious problem to rice production in central zone of Adamawa state and was ranked $1^{\text {st }}$ by the respondents.

TABLE 6 


\section{Thematics Journal of Geography}

\begin{tabular}{lllrl}
\hline Rank & Constraints & Percentage & Position & $\begin{array}{c}\text { Garret table } \\
\text { (scores) }\end{array}$ \\
\hline 1 & Shortage of labour & $100(1-0.5) / 10$ & 5 & 82 \\
2 & Clashes with & & & \\
& pastoralists & $100(2-0.5) / 10$ & 15 & 71 \\
3 & Inadequate farm credit & $100(3-0.5) / 10$ & 25 & 64 \\
4 & Striga infestation & $100(4-0.5) / 10$ & 35 & 58 \\
5 & Inadequate rainfall & $100(5-0.5) / 10$ & 45 & 53 \\
6 & Shortage/high cost of & & & 48 \\
& inputs & $100(6-0.5) / 10$ & 55 & 43 \\
7 & Pests and diseases & $100(7-0.5) / 10$ & 65 & 37 \\
8 & Birds infestation & $100(8-0.5) / 10$ & 75 & 30 \\
9 & Inadequate research & & & \\
& and extension support & $100(9-0.5) / 10$ & 85 & 19 \\
10 & Land tenure & $100(10-0.5) / 10$ & 95 & \\
& & & & \\
\hline
\end{tabular}

\section{Percentage Positions and their corresponding Garrett's Table values}

This is in line with what Adedeji et al. (2017) reported in their study on the effect of climate change on rice production in Adamawa State, Nigeria, that rainfalls and temperature were the major climatic factors that affect rice production such that $1 \%$ increase in rainfall leads to $22.2 \%$ increase in rice production.

Labour has special contributions in the production of rice in other words it is the fundamental and active factor of production. Farmers complain bitterly on high cost and inadequate supply of physical, mental, productive, skilled and unskilled labour in the study area. It was ranked $2^{\text {nd }}$ by the respondents. This agreed with what Kwinarajit and Gary 2004 reported that shortage of labour is a major factor affecting Thai rice in their study on economic factors affecting rice production in Thailand. Clashes betweenrice farmers and pastoralists over grazing fields are common in northern Nigeria and are increasing throughout the country as pastureland shrinks. It usually occurs when herdsman led their cattle into rice fields and grazed on the crops. This often results in a serious conflict where scores of houses were completely burnt and crops on several farms were destroyed. Although the Nomads complain that wherever they turn and find out that the land reserved for their cattle to feast, were taken over by farmers. It becomes difficult for their herd to move and graze without veering into crop fields. It was ranked $3^{\text {rd }}$ by the respondents in the study area.

Striga also known as witch weed parasitizes is capable of significantly reducing yields, in some cases wiping out the entire crop. Each plant is capable of producing between 90,000 and 500,000 seeds, which may remain viable in the soil for over 10 years. Management of witch weed is difficult because majority of its life cycle takes place below ground; but if populations are low, hand weeding before seeds are produced is an option (Wikipedia, 2018). It was ranked $4^{\text {th }}$ by the respondents in the study area. The 
findings accord the report by Evans et al. (2011) that notable advances in Striga weed control technology have been made, yet the weed continues to be a major cause of low agricultural production in their study on Evaluation of ecologies and severity of Striga weeds on rice in sub-Saharan Africa. The availability of credit can affect fixed production costs and farmers will use fewer seeds and fertilizer if they are credit constrained (Brambilla and Porto, 2005). Credit may influence farmers' participation

\section{Conclusion and Recommendations}

This paper analyses the economics of rice production in central agricultural zone of Adamawa state, Nigeria. The results indicated that rice production is profitable with net income over cost $A_{1}$ which is the direct cost involved in rice production of $\$ 146,049.11$; while over cost $C_{3}$ which is the total cost of cultivation of rice was $\$ 100,083.62$. The stochastic cost frontier model shows a mean allocative efficiency of 0.89 which indicated that an average farmer in the study area has the scope for increasing in marketing systems and increase their ability to generate higher incomes through its effect on production, output and marketing costs. Inadequate farm credit was ranked $5^{\text {th }}$ by the respondents. Ibrahim (2014) also reported that poor provision of credit facilities as the major adoption decision on rice production technologies by farming households under Borno state Agricultural Development Programme, Nigeria.

allocative efficiency by 11 per cent in the short-run under the existing technology. Inadequate rainfall, shortage of labour, clashes with pastoralist was the major constrains associated with rice production in the study area. The study suggest that government policies should be geared towards developing and establishing new fertilizer and agro-chemicals industries to ease the cost of inputs as well as intensify farmer grazer conflict resolution programmes. 
TABLE 7

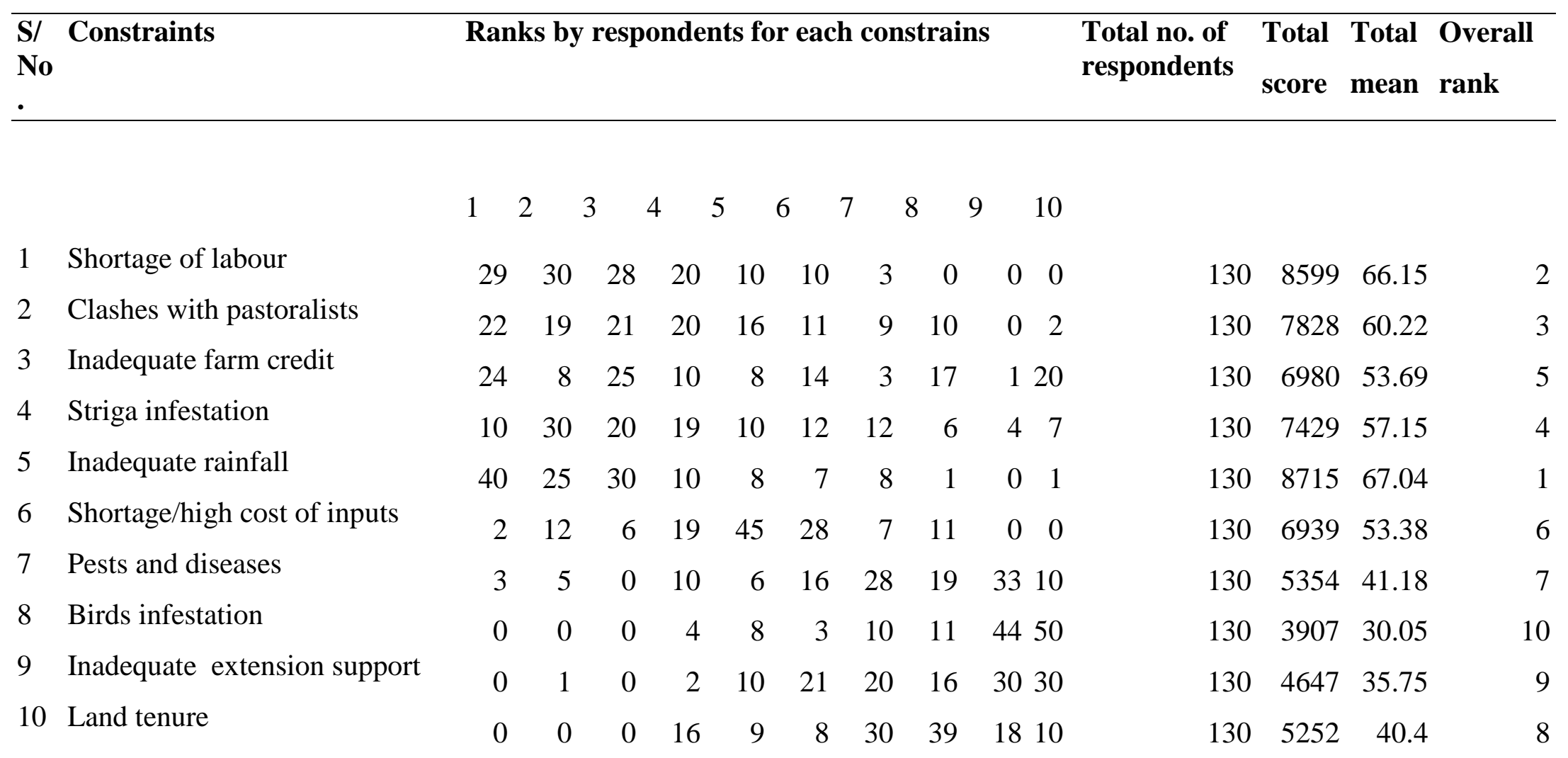

\footnotetext{
Ranking Constraints associated to rice production in central Agricultural zone of Adamawa State
} 


\section{REFERENCES}

Adedeji, N.E., Tiku, N.E., Waziri- Ugwu,P.R., and Sanusi, S.O. (2017). The effect of climate change on rice production in Adamawa State, Nigeria. Agroeconomia Croatica, 7(1), $1-13$.

Evans, A. A., Kazuyuki, I. and John C.O. (2011). Evaluation of ecologies and severity of Striga weed on rice in Sub-Saharan Africa. Agriculture and Biology Journal of North America. 2(5), 752-760.

FAOSTAT, (2018). Rice paddy Data base. Accessed 21 ${ }^{\text {st }}$ march, 2018. http://www.fao.org/faostat/en/\#data/QC

Girei, A.A., Usman, I.S. and Onuk, E.G. (2016). Profitability Investigation of Rice Production in Fufore Local Government Area of Adamawa State, Nigeria. European Journal of Academic Essays, 3(3),137-140.

Ibrahim, A.A. (2014). Adoption decision on rice production technologies by farming households under Borno state Agricultural Development Programme, Nigeria. International Journal of Research in Agriculture and Food Sciences. 2(3), 26-31.

Jagdish, K. and Prakash, K.K. (2008). Contract Farming: Problems, Prospects and its Effect on Income and Employment, Agricultural Economics Research Review, 21, 243-250.

Kwinarajit, S. and Gary, W.W. (2004). Economic Factors Affecting Rice Production in Thailand TAMRC International Research Report No. IM-03-04 March 2004, 1-23.

Matanmi, B.M., Adesiji , G.B., Owawusi, W.O. and Oladipo, F.O. (2011). Perceived Factors Limiting Rice Production in Patigi Local Government Area of Kwara State, Nigeria. Journal of Agriculture and Social Research (JASR), 11(2), 40-45.

Narayanamoorthy, A. (2013). Profitability in Crops Cultivation in India: Some Evidence from Cost of Cultivation Survey Data. Ind. Jn. of Agri. Econ, 68(1).

Nigeria Economy Starts, (2012). Nation master. Retrieved from http//www.nationmaster.com/country-info/profits/Nigeria/Economy

Sajo, A.A. and Kadams, A.M. (1999). Food and Cash Crops: In Adamawa State in Maps, Adebayo, A.A. and Tukur A.L. (eds). Paraclete Publishers, Yola, Nigeria.

Samarpitha, A., Vasudev, N. and Suhasini, K. (2016). Technical, economic and allocative efficiencies of rice farms in Nalgonda district of Telangana state. Economic Affairs Citation: EA: 61(3), 365-374. 
Sanusi, M. (2014). Rice Farming in Nigeria: Challenges, Opportunities and Prospects. A paper presentation at the $2^{\text {nd }}$ Nigeria Rice Investment Forum (NIRIF), Ladi kwalli hall, Abuja Sheraton hotel, Abuja.

Sihlongonyane, M.B., Masuku, M.B. and Belete, A. (2014). Economic Efficiency of Maize Production in Swaziland: The Case of Hhohho, Manzini and Shiselweni Regions. Research in Applied Economics, 6(3),179.

Trading Economics, (2018). Nigeria GDP from agriculture. https://tradingeconomics.com/nigeria

Usman, J. (2018) .Cost and Return Analysis of Rice Production in Song local government area of Adamawa state, Nigeria. International Journals of Advances in Agricultural Science and Technology. 5(2), 55-62.

Wikipedia, (2018). The free encyclopedia. https://en.wikipedia.org/wiki/Striga. Access on 22 February, 2018.

Wu, C.C. (1979). Price-Output Uncertainty and Allocative Efficiency: An Empirical Study of Small- Scale Farms.1979. The Review of Economics and Statistics, 601(2), 22-82. http://dx.doi.org/10.2307/1924590,1979

Xu, X. and Jeffrey, S.R. (1998). Efficiency and Technical Progress in Traditional and Modern Agriculture, Evidence from Rice Production in China. Agricultural Economics Journal, 18, 157-165. 